\title{
Implementation of Teacherpreneurship on Teachers at Vocational High School
}

\author{
Herminanto Sofyan, Adhan Efendi \\ Universitas Negeri Yogyakarta \\ Yogyakarta, Indonesia \\ hermin@uny.ac.id
}

\begin{abstract}
This study aims to increase: (1) the professionalism of teachers with teacherpreneurship implementation at SMK Negeri 2 Depok and SMK Negeri 1 Muhammadiyah Bantul, and (2) the response to the increase in the professionalism of teachers with teacherpreneurship implementation. The research is classroom action research. The research consists of cycle I, cycle II, and cycle III. In each cycle, there are planning, action, observation, and reflection. Data were analyzed using descriptive analysis techniques to the data collected through observation, documentation, and interviews. The results of this study indicate the implementation of teacher professionalism at the two schools can be viewed from three aspects: competence, creativity, and effectiveness. The increase in professionalism of teachers at SMK Negeri 2 Depok from the first cycle to the second cycle is $(23.18 \%)$ and the increase from the second cycle to the third cycle is $(\mathbf{1 6 . 8 2 \%})$, while the increase in the professionalism of teachers in SMK Muhammadiyah 1 Bantul from the first cycle to the second cycle is $(\mathbf{2 5 . 4 2 \%})$ and an increase from the second cycle to the third cycle is $(13.07 \%)$.
\end{abstract}

Keywords - entrepreneurship; implementation of teacherpreneurship; teachers professionalism

\section{INTRODUCTION}

Advances in science and technology have made the competition for human resources in global era become unavoidable. A highly competitive workforce in the global era has been prepared by all developed countries [6]. In Indonesia, the strengthening of vocational education is one of the priorities. An educated and skilled workforce is needed to sustain economic growth targeted by the government. The government's efforts on facing global competition are expected to improve the economy of Indonesia.

Both theory and practice of teaching and learning process in vocational high school (SMK) and in the industry are expected to produce qualified graduates. SMK prioritizes the preparation of students who have the competencies required to enter the employment field. However, the facts mentioned SMK still not able to produce maximum high-quality graduates. Data from the Central Bureau of Statistics in Indonesia shows that the number of unemployed SMK graduates is greater than senior high school (SMA) that is $11.24 \%$ per August 2014 while the unemployment rate of high school graduates is $9.55 \%$ per August 2014. These data indicate the low quality of SMK graduates. The low quality of SMK is a problem that many stakeholders have complained about ${ }^{[1]}$. Teaching and learning in classes that have not been up become one of the factors causing the emergence of the problem.

Teaching-learning process in the classroom that happens between teacher and student becomes the determinant of obtaining the result according to the stakeholder's expectation. A teacher is an important key of maximum education quality ${ }^{[8]}$. Teachers or instructors must have competence and experience in the industry, as well as knowledge of the current state of practice ${ }^{[2]}$. Teacher competence can be obtained from education and training programs that become government programs.

Education and training programs (DIKLAT) cannot be effectively implemented according to the competency needs of teachers. ${ }^{[11]}$ The improvement of education quality in vocational school has not run effectively. Training is carried out only to meet the demands of the project, not based on the needs and problems in the field experienced by a teacher in terms of learning implementation. Some factors contributing to the ineffective implementation of DIKLAT yet lies in planning and poor training models to accommodate existing needs. The quality improvement program implemented by the government is expected to improve the professionalism of teachers in accordance with the areas of expertise.

Teachers should be aware that their professionalism is an important task of the teaching profession. To be professional requires a process whereby the teachers themselves are ultimately able to measure the extent of learning ${ }^{[5]}$. Teacher professionalism includes teachers' skills in terms of competence and ability of teachers in the process of improving the quality of education that should be more creative and effective. ${ }^{[9]}$ The positive attitudes adoption of an entrepreneur can be applied by teachers in SMK. An entrepreneur must have good competence in his field; have a creative attitude in developing products, packaging, and delivery of products, as well as active in various development activities, and effective in product marketing. Adoption of the positive nature of entrepreneurs does not make teachers to switch professions from a teacher to become entrepreneurs, but to make teachers 
apply the nature of an entrepreneur in the process of teaching and learning in vocational schools.

The adoption applied in a world of vocational education is called edupreneurship. Edupreneurship is an amalgamation and collaboration between technopreneuship (for students), teacherpreneurship (for teachers), and schoolpreneurship (for school). ${ }^{[7]}$ Teacherpreneur does not make the teachers to become the entrepreneurs but does make the teachers to have the entrepreneurial spirit. Teacherpreneur model has not been done empirically, so it is necessary to implement teacherpreneurship so that this model can be applied in general to vocational school later. This study aims to improve the professionalism of vocational teachers through teacherpreneurship and to know the teacher's response to teacherpreneurship.

\section{RESEARCH METHOD}

This is a classroom action research. The research is classroom action research. Data were analyzed using descriptive analysis techniques to the data collected through observation, documentation, and interviews. This research was conducted at SMK in Yogyakarta namely SMK Negeri 2 Depok and SMK Muhammadiyah 1 Bantul. These schools were chosen because they have an "A" school accreditation and they also become school reference with the number of students nearly 1000 .

The subjects of this study were all productive teachers of automotive engineering majoring teaching that consist of 4 teachers in each school. Criteria and considerations in the subject of this study are professionalism of teachers which include: aspects of competence, creativity, and effectiveness of productive teachers with the benchmark achievement average professional proficiency of at least $85 \%$. After the forum group discussions (FGD) had been conducted, the observer observed the teacher while the learning process took place in the workshop from opening to closing of the learning process to see the implementation of teacherpreneurship.

This research consists of cycle I, cycle II, and cycle III. Each cycle has 4 stages which are planning, action, observation, and reflection. The four stages of each cycle will always recur. The result of reflection from the previous cycle that has been used will be reused to revise the lesson plan if the action that has been done cannot solve the problem in the learning activity. Kemmis model is used by researcher because it is can be used in the process of conducting research and in accordance with the goal of teacher professional enhancement.

The research instruments used are an observation sheet and an interview guide. Data analysis techniques are used to answer the formulation of problems that have been formulated in the research. In classroom action research, the analysis is carried out by researchers from the beginning on every aspect reviewed. The learning process and teacher teaching attitude changes reviewed are described according to the observations made by the observers in each cycle. In addition, the learning process and teacher attitude change are categorized according to their respective reviews. It is useful to know the description of the data in each aspect reviewed. The data obtained in this classroom action research is the result of observation of teacher teaching attitude in the form of competence, creativity, and effectiveness data.

Descriptive analysis of this action research is used to determine the mean (M), median (Me), maximum score (Max), minimum score (Min) and standard deviation (SD). To describe or to know the trends of the aspects reviewed in this study, the researcher used the ideal score and the ideal score of at least four categories of competence review, creativity, and effectiveness of teachers whether very good, good or not. Here are the categories to describe the conditions of competence, creativity, and effectiveness to be reviewed.

TABLE 1. Overview Data Description Categorization of Teacher Competence, Creativity and Effectiveness Aspect

\begin{tabular}{|ccc|}
\hline No & Trends & Category \\
& & \\
\hline 1 & $(\mathrm{Mi}+1,5 \mathrm{Sbi})<\mathrm{X} \leq \mathrm{Maximum}$ Score & Very Good \\
2 & $\mathrm{Mi}<\mathrm{X} \leq(\mathrm{Mi}+1,5 \mathrm{Sbi})$ & Good \\
3 & $(\mathrm{Mi}-1,5 \mathrm{Sbi})<\mathrm{X} \leq \mathrm{Mi}$ & Enough \\
4 & Minimum Score $<\mathrm{X} \leq(\mathrm{Mi}-1,5 \mathrm{Sbi})$ & Poor \\
\hline
\end{tabular}

\section{RESEARCH RESULTS AND DISCUSSION}

\section{A. Research Results}

\section{Cycle I Condition}

The action in cycle $\mathrm{I}$ is the result of a problems diagnosis occurring during pre-cycle conditions. In general, cycle I consists of several stages including planning, implementation, observation, and reflection. Problems that arise during precycle conditions include aspects of competence, creativity, and effectiveness of teachers in implementing teacherpreneurship to improve teacher professionalism. The application of the entrepreneurship spirit to the teacher is still in the less category that has not reached the teacher professional achievement indicator or achieved very good category.

Researchers conducted the action in the form of forum group discussions (FGD) by conducting discussions between researchers, observers, and teachers about teacherpreneurship. FGD conducted for approximately 60 minutes in the form of a discussion about the introduction of teacherpreneurship, teacherpreneurship components, advantages and disadvantages, and implementation of good teacherpreneurship.

After FGD had been conducted, the observers observed the teacher while the learning process took place in the workshop from opening to closing of the learning process to see the implementation of teacherpreneurrsip. The result of observation on 4 teachers conducted in SMK Negeri 2 Depok on the aspect of competence obtained Mean $(\mathrm{M})=52.0$; Median $(\mathrm{Me})=51.0$; Standard Deviation $(\mathrm{SD})=2.828$; Minimum $(\operatorname{Min})=50 ;$ And Maximum $(\operatorname{Max})=56$. The results of observations on 4 teachers conducted in SMK Negeri 2 Depok on the aspect of creativity obtained Mean $(\mathrm{M})=28.0$; 
Median $(\mathrm{Me})=27.5$; Standard Deviation $(\mathrm{SD})=2.160$; Minimum $($ Min $)=26$; and Maximum $(\operatorname{Max})=31$. The results of observations on 4 teachers conducted in SMK Negeri 2 Depok on the effectiveness obtained Mean $(\mathrm{M})=13.0$; Median $(\mathrm{Me})=13.0 ;$ Standard Deviation $(\mathrm{SD})=816$; Minimum $(\operatorname{Min})=12$; and Maximum $(\operatorname{Max})=14$. A summary of the description categories for the competence, creativity, and effectiveness of 4 teachers of SMK Negeri 2 Depok can be seen in Table 2.

TABLE 2. Description Category Summary of Teacher Professionalism at SMK Negeri 2 Depok in Cycle I

\begin{tabular}{|lll|}
\hline No & Category & Percentage (\%) \\
\hline 1 & Very Good & 0 \\
2 & Good & 0 \\
3 & Enough & $100 \%$ \\
4 & Poor & 0 \\
\hline Total & & $100 \%$ \\
\hline
\end{tabular}

Table 2 describes teacher professionalism in cycle I consisting of aspects of competence, creativity, and effectiveness. Four teachers in the observation are in enough category $(100 \%)$. The average achievement of four teachers has not achieved the expected result of $85 \%$.

Furthermore, the results of the observation of four teachers conducted in SMK Muhammadiyah 1 Bantul on the aspect of competence obtained Mean $(\mathrm{M})=48.5$; Median $(\mathrm{Me})=48.5$; Standard Deviation $(\mathrm{SD})=1.290$; Minimum $(\mathrm{Min})=47$; and Maximum $(\operatorname{Max})=50$. The result of observation of four teachers conducted at SMK Muhammadiyah 1 Bantul on creativity aspect obtained Mean $(\mathrm{M})=25.25$; Median $(\mathrm{Me})=$ 24.50; Standard Deviation $(\mathrm{SD})=1.892$; Minimum $(\mathrm{Min})=$ 24 ; and Maximum $(\operatorname{Max})=28$. The result of the observation of four teachers conducted at SMK Muhammadiyah 1 Bantul on the effectiveness aspect obtained Mean $(\mathrm{M})=11.0$; Median $(\mathrm{Me})=11.0$; Standard Deviation $(\mathrm{SD})=816$; Minimum $(\mathrm{Min})$ $=10$; And Maximum $(\operatorname{Max})=12$. A summary of the description categories for the competence, creativity, and effectiveness of the four teachers of SMK Muhammadiyah 1 Bantul can be seen in Table 3.

TABLE 3. Description Category Summary of Teacher Professionalism at SMK Muhammadiyah 1 Bantul Cycle I

\begin{tabular}{|lll|}
\hline No & Category & Percentage (\%) \\
\hline 1 & Very Good & 0 \\
2 & Good & 0 \\
3 & Enough & $100 \%$ \\
4 & Poor & 0 \\
\hline Total & & $100 \%$ \\
\hline
\end{tabular}

Table 3 describes teacher professionalism in cycle I consisting of aspects of competence, creativity, and effectiveness. Four teachers in the observation are in enough category $(100 \%)$. The average achievement of four teachers has not achieved the expected result of $85 \%$.

Cycle II Condition
The action given in cycle II is the result of the diagnosis of problems occurring during cycle I condition. In general, cycle II consists of several stages including planning, implementation, observation, and reflection. Problems that arise during cycle I condition include competency aspect, creativity, and effectiveness of teacher in implementing teacherpreneurship to improve teacher professionalism as well as inculcate entrepreneurship spirit in teacher still not reach the expected result.

Researchers perform actions in the form of education and training (DIKLAT) through the presentation of teacherpreneurship material and the provision of teacherpreneurship implementation modules. DIKLAT was done less for 90 minutes with the discussion about the introduction of teacherpreneurship, teacherpreneurship components, advantages and weaknesses of teacherpreneurship, implementation of teacherpreneurship, then question and answer between researchers, observers, and teachers.

After DIKLAT, observers observed the teacher during the learning process that takes place in workshops ranging from opening to closing of the learning process to see the implementation of teacherpreneurship. The result of observation of four teachers conducted at SMK Negeri 2 Depok on the aspect of competence obtained Mean $(\mathrm{M})=$ 63.25; Median $(\mathrm{Me})=63.0$; Standard Deviation $(\mathrm{SD})=5000$; Minimum $(\operatorname{Min})=63$; and Maximum $(\operatorname{Max})=64$. The result of observation of four teachers conducted at SMK Negeri 2 Depok on creativity aspect obtained price Mean $(\mathrm{M})=42.50$; Median $(\mathrm{Me})=4.50$; Standard Deviation $(\mathrm{SD})=1.290$; Minimum $($ Min $)=41$; and Maximum $(\operatorname{Max})=44$. The results of the observation of four teachers conducted in SMK Negeri 2 Depok on the effectiveness of the obtained price Mean (M) $=19.25 ;$ Median $(\mathrm{Me})=19,0 ;$ Standard Deviation $(\mathrm{SD})=$ 5000; Minimum $(\operatorname{Min})=19 ;$ And Maximum $(\operatorname{Max})=20$. Summary of description categories for the competence, creativity and effectiveness of the four teachers of SMK Negeri 2 Depok can be seen in Table 4.

TABLE 4. Description Category Summary of Teacher Professionalism at SMK Negeri 2 Depok in Cycle II

\begin{tabular}{|lll|}
\hline No & Category & Percentage (\%) \\
\hline 1 & Very Good & 0 \\
2 & Good & $100 \%$ \\
3 & Enough & 0 \\
4 & Poor & 0 \\
\hline Total & & $100 \%$ \\
\hline
\end{tabular}

Table 4 describes teacher professionalism in cycle II consisting of aspects of competence, creativity, and effectiveness. Four teachers in the observation are in good category (100\%). The average achievement of four teachers has not achieved the expected result of $85 \%$.

Furthermore, the results of the observations of four teachers conducted in SMK Muhammadiyah 1 Bantul on the aspect of competence obtained price Mean $(\mathrm{M})=67.75$; 
Median $(\mathrm{Me})=67.50 ;$ Standard Deviation $(\mathrm{SD})=9574$; Minimum $(\operatorname{Min})=67$; And Maximum $(\operatorname{Max})=69$. The result of observation of four teachers conducted at SMK Muhammadiyah 1 Bantul on creativity aspect obtained price Mean $(\mathrm{M})=44,0 ;$ Median $(\mathrm{Me})=44,0$; Standard Deviation $(\mathrm{SD})=1,825 ;$ Minimum $(\operatorname{Min})=42$; And Maximum $(\operatorname{Max})=$ 46. The result of observation of four teachers conducted at SMK Muhammadiyah 1 Bantul on effectiveness aspect obtained price Mean $(\mathrm{M})=17,75 ; \operatorname{Median}(\mathrm{Me})=18,0$; Standard Deviation $(\mathrm{SD})=5000$; Minimum $(\mathrm{Min})=17$; And Maximum $(\operatorname{Max})=18$. Summary of category description for competence, creativity, and effectiveness of four teachers of SMK Muhammadiyah 1 Bantul can be seen in Table 5.

TABLE 5. Description Category Summary of Teacher Professionalism at SMK Muhammadiyah 1 Bantul in Cycle II

\begin{tabular}{|lll|}
\hline No & Category & Percentage (\%) \\
\hline 1 & Very Good & 0 \\
2 & Good & $100 \%$ \\
3 & Enough & 0 \\
4 & Poor & 0 \\
\hline Total & & $100 \%$ \\
\hline
\end{tabular}

Table 5 describes the professionalism of teachers in cycle II consisting of aspects of competence, creativity, and effectiveness. Four teachers in the observation are in the big category $(100 \%)$. The average achievement of four teachers has not achieved the expected result of $85 \%$.

\section{Cycle III Condition}

The action given in cycle III is the result of a diagnosis of the problems that occur during cycle II condition. In general, cycle III consists of several stages including planning, implementation of action, observation, and reflection. Problems that arise during cycle II condition include competency aspect, creativity, and effectiveness of teacher in implementing teacherpreneurship to improve teacher professionalism as well as inculcating entrepreneurship spirit in teacher which still not reach the expected result.

Researchers take action in the form of training to make the work of a joint practice between researchers, observers and teachers do the practice of Maxing the car alarm that can later be taught to students. This training is the researcher's effort to improve teacher's creativity in implementing teacherpreneurship. Training to make the car alarm work done starting from the introduction of tools and materials used, how to assemble components, and question and answer with the teacher.

After the training has been conducted, the observer observed the teacher during the learning process took place in the workshop from opening to closing the learning process to see the implementation of teacherpreneurship. The result of observation of four teachers conducted at SMK Negeri 2 Depok on the aspect of competence obtained price Mean (M) $=75,25$; Median $(\mathrm{Me})=75,50$; Standard Deviation $(\mathrm{SD})=$ 9574; Minimum $(\operatorname{Min})=74$; And Maximum $(\operatorname{Max})=76$. The result of observation of four teachers conducted at SMK
Negeri 2 Depok on creativity aspect obtained price Mean (M) $=55,25 ;$ Median $(\mathrm{Me})=55,0 ;$ Standard Deviation $(\mathrm{SD})=$ 5000; Minimum $(\operatorname{Min})=55$; And Maximum $(\operatorname{Max})=56$. The fourth observation conducted in SMK Negeri 2 Depok on the effectiveness aspect obtained the price of Mean $(\mathrm{M})=22,0$; Median $(\mathrm{Me})=22,0 ;$ Standard Deviation $(\mathrm{SD})=8165$; Minimum $($ Min $)=21$; And Maximum $(\operatorname{Max})=23 . \mathrm{A}$ summary of the description categories for the competence, creativity, and effectiveness of the four teachers of SMK Negeri 2 Depok can be seen in Table 6.

TABLE 6. Description Category Summary of Teacher Professionalism at SMK Negeri 2 Depok in Cycle III

\begin{tabular}{|lll|}
\hline No & Category & Percentage (\%) \\
\hline 1 & Very Good & $100 \%$ \\
2 & Good & 0 \\
3 & Enough & 0 \\
4 & Poor & 0 \\
\hline Total & & $100 \%$ \\
\hline
\end{tabular}

Table 6 describes teacher professionalism in cycle III consisting of aspects of competence, creativity, and effectiveness. Four teachers in the observation are in very good category (100\%). The average achievement of four teachers has achieved the expected outcome of $85 \%$.

Furthermore, the results of the observation of four teachers conducted in SMK Muhammadiyah 1 Bantul on the aspect of competence obtained price $\operatorname{Mean}(\mathrm{M})=77.25$; Median $(\mathrm{Me})=$ 77.50; Standard Deviation $(\mathrm{SD})=9573$; Minimum $($ Min $)=$ 76; And Maximum $(\operatorname{Max})=78$. The result of observation of four teachers conducted at SMK Muhammadiyah 1 Bantul on creativity aspect obtained price Mean $(\mathrm{M})=54,0$; Median $(\mathrm{Me})=54,0 ;$ Standard Deviation $(\mathrm{SD})=8165 ;$ Minimum $(\operatorname{Min})=53$; and Maximum $(\operatorname{Max})=55$. The result of observation of four teachers conducted at SMK Muhammadiyah 1 Bantul on effectiveness aspect obtained Mean $(\mathrm{M})=21.75 ;$ Median $(\mathrm{Me})=22.0$; Standard Deviation $(\mathrm{SD})=5000$; Minimum $(\operatorname{Min})=21$; and Maximum $(\operatorname{Max})=$ 22. Summary of category description for competence, creativity, and effectiveness of four teachers at SMK Muhammadiyah 1 Bantul can be seen in Table 7.

TABLE 7. Description Category Summary of Teacher Professionalism at SMK Muhammadiyah 1 Bantul in Cycle III

\begin{tabular}{|lll|}
\hline No & Category & Percentage (\%) \\
\hline 1 & Very Good & $100 \%$ \\
2 & Good & 0 \\
3 & Enough & 0 \\
4 & Poor & 0 \\
\hline Total & & $100 \%$ \\
\hline
\end{tabular}

Table 7 describes teacher professionalism in cycle III consisting of aspects of competence, creativity, and effectiveness. Four teachers in the observation are in very good category $(100 \%)$. The average achievement of four teachers has achieved the expected outcome of $85 \%$. 


\section{B. Discussion}

Teacherpreneurship Implementation on teachers at SMK Negeri 2 Depok.

\section{Teacher Acquisition Process in Cycle I}

The average score of professionalism of teachers in cycle I was $(55.75 \%)$. Improvement occurs in all aspects of teacherpreneurship both aspects of competence, creativity, and effectiveness. The greatest improvement is in the aspect of competence. This is because teachers are interested in implementing teacherpreneurship and motivated to improve their skills. The smallest increase occurs in the aspect of creativity and effectiveness. This is considered reasonable because of there are many creativity aspects to the practice in the classroom. Teachers need to understand the theory of teacherpreneurship and also implement teacherpreneurship. The effectiveness aspect is seen when students have completed one competency and conducted the theory and practice exams.

TABLE 8. Observation Result of Teacher Professionalism Cycle I at SMK Negeri 2 Depok

\begin{tabular}{|lllll|}
\hline & Frequency & Percentage & Valid Percentage & Mean \\
\hline $\begin{array}{l}\text { Valid } \\
\text { Enough }\end{array}$ & 4 & 100.0 & 100.0 & $55.75 \%$ \\
\hline
\end{tabular}

Table 8 indicates the professional attainment of four teachers in cycle I was $(55.75 \%)$ and was in enough category.

\section{Teacher Acquisition Process in Cycle II}

Obtained professional score of cycle II is equal to $(78,24 \%)$. Improvement occurs in all aspects of teacherpreneurship that are the aspects of competence, creativity, and effectiveness. The greatest improvement is in the aspect of competence. This is because teachers have understood teacherpreneurship more fully and deeply and how to implement it. Teachers also read modules that have been made by researchers so that teachers can understand teacherpreneurship better and discuss it with fellow teachers. While the increase is good enough can be seen in the aspect of competence and effectiveness although not as much as an increase in the aspect of competence. This is considered reasonable because the improvement of the creativity aspect should be done in practice and the aspect of effectiveness is seen when a competence is finished taught and tested.

TABLE 9. Observation Result of Teacher Professionalism Cycle II at SMK Negeri 2 Depok

\begin{tabular}{|lllll|}
\hline & Frequency & Percentage & Valid Percentage & Mean \\
\hline $\begin{array}{l}\text { Valid } \\
\text { Enough }\end{array}$ & 4 & 100.0 & 100.0 & $78.34 \%$ \\
\hline
\end{tabular}

Table 9 indicates the professional attainment of four teachers in cycle II was (78.34\%) and was in good category.
TABEL 10. Observation Result of Teacher Professionalism Cycle II at SMK Negeri 2 Depok

\begin{tabular}{|ccc|}
\hline $\begin{array}{c}\text { Teacher } \\
\text { Professionalism Cycle } \\
\text { I }\end{array}$ & $\begin{array}{c}\text { Teacher } \\
\text { Professionalism Cycle } \\
\text { II }\end{array}$ & $\begin{array}{c}\text { Teacher } \\
\text { Professionalism } \\
\text { Increase }\end{array}$ \\
\hline $\begin{array}{c}\text { Category } \\
\text { Enough }(55.75 \%)\end{array}$ & $\begin{array}{c}\text { Category } \\
\text { Good }(78.34 \%)\end{array}$ & $22.59 \%$ \\
\hline
\end{tabular}

Table 10 describes teacher professionalism in cycle I is in enough category $(55.75 \%)$ and increase in cycle II become good category $(78.34 \%)$. Enhancement of professional teacher in cycle I to cycle II is equal to (22.59\%). Increased professionalism of teachers includes aspects of competence, creativity, and effectiveness of teachers while teaching in the classroom $^{[11]}$. The presentation in the form of the histogram cycle I and cycle II is as follows:

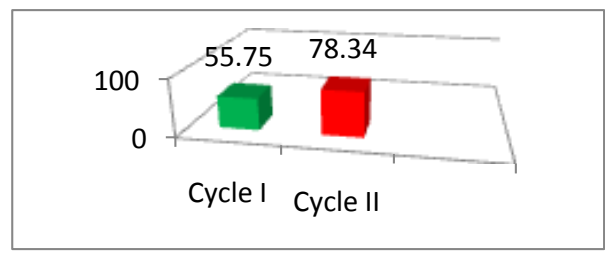

Figure 1. Teacher Professionalism Increase (Cycle I-Cycle II)

Figure 1 illustrates the increase that occurs during cycle I to cycle II is from enough category (55.75) to good category (78.34).

\section{Teacher Acquisition Process in Cycle III}

Teacher professionalism improvement in cycle III is indicated by obtaining average $(94.57 \%)$. Improvement occurs in all aspects of teacherpreneurship in the aspects of competence, creativity, and effectiveness. The most significant improvement occurred in the aspect of creativity. It also supported by the results of interviews to teachers that training makes teachers more motivated to be creative in the learning process.

TABLE 11. Observation Result of Teacher Professionalism Cycle III at SMK Negeri 2 Depok

\begin{tabular}{|lllll|}
\hline & Frequency & Percentage & Valid Percentage & Mean \\
\hline $\begin{array}{l}\text { Valid Very } \\
\text { Good }\end{array}$ & 4 & 100.0 & 100.0 & $94.57 \%$ \\
\hline
\end{tabular}

Table 11 indicates the professionalism attainment of four teachers in cycle III was $(94.57 \%)$ and was in good category.

TABEL 12. Observation Result of Teacher Professionalism Cycle III at SMK Negeri 2 Depok

\begin{tabular}{|c|c|c|}
\hline $\begin{array}{c}\text { Teacher } \\
\text { Professionalism Cycle } \\
\text { II }\end{array}$ & $\begin{array}{c}\text { Teacher } \\
\text { Professionalism Cycle } \\
\text { III }\end{array}$ & $\begin{array}{c}\text { Teacher } \\
\text { Professionalism } \\
\text { Increase }\end{array}$ \\
\hline Category & Category & \\
\hline Good $(78.34 \%)$ & Very Good $(94.57 \%)$ & $16.82 \%$ \\
\hline
\end{tabular}


Table 12 describes teacher professionalism in cycle II is in good category $(78,34 \%)$ increase in cycle III become very good category $(94,57 \%)$. The improvement of professional teacher in cycle II to cycle III is equal to $(16,82 \%)$. Researchers perform training actions to make car alarms so that teachers become more creative in teaching. Seminar and training programs are very effective in improving the creativity of new teachers. Creativity building for teachers needs to be implemented systematically, continuously, and evenly from base to substantial. The presentation in the form of histogram shows the improvement in cycle I and cycle II is as follows.

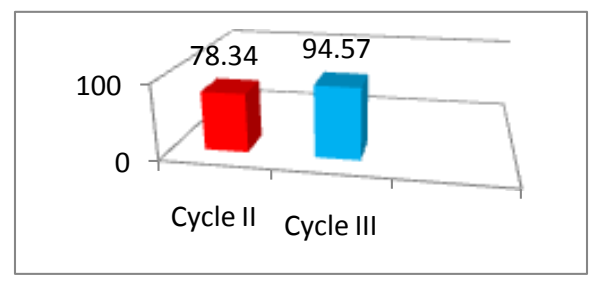

Figure 2. Teacher Professionalism Increase (Cycle II-Cycle III)

Figure 2 illustrates the increase that occurs during cycle II to cycle III is from $78.34 \%$ to $94.57 \%$.

The increase of teacherpreneurship implementation in general is shown in the following histogram.

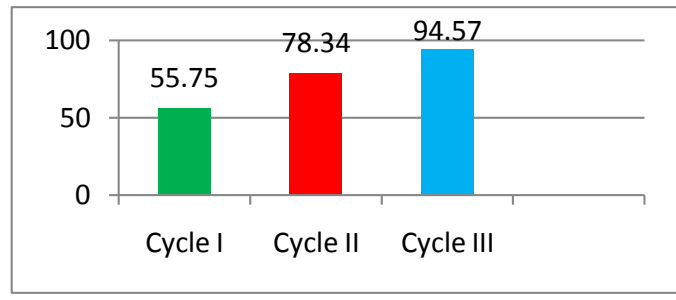

Figure 3. Teacher Professionalism Increase

Teacherpreneurship Implementation of teachers at SMK Muhammadiyah 1 Bantul.

\section{Teacher Acquisition Process in Cycle I}

The increase in professionalism of the four teachers in cycle I was (53.72\%). Improvement occurs in all aspects of teacherpreneurship including aspects of competence, creativity, and effectiveness. The greatest improvement is in the aspect of competence. This is because teachers are interested and motivated in implementing teacherpreneurship better and improving their abilities. The smallest increase occurs in the aspect of creativity and effectiveness. This is considered reasonable because the creativity aspect is more to the practice in the classroom so that teachers need to implement not only understand the theory of teacherpreneurship. While the effectiveness aspects are seen when students have completed one competency and executed the theory and practice exams.

TABLE 13. Teacher Professionalism Observation Result Cycle I at SMK Muhammadiyah 1 Bantul

\begin{tabular}{|lllll|}
\hline & Frequency & Percentage & Valid Percentage & Mean \\
\hline $\begin{array}{l}\text { Valid } \\
\text { Enough }\end{array}$ & 4 & 100.0 & 100.0 & $53.72 \%$ \\
\hline
\end{tabular}

Table 13 indicates the professionalism attainment of four teachers in cycle I was (55.75\%) and was in enough category.

\section{Teacher Acquisition Process in Cycle II}

The professionalism of the four teachers at SMK Muhammadiyah 1 Bantul in cycle II is (79.21\%). Improvement occurs in all aspects of teacherpreneurship (aspects of competence, creativity, and effectiveness). The greatest improvement is in the aspect of competence, this is because the teacher has understood teacherpreneurship more fully and deeply and how to implement it. Teachers also read modules that have been made by researchers so that teachers can better understand teacherpreneurship and discuss it with fellow teachers. While the significant increase seen in the aspect of competence and effectiveness, although not as much as an increase in the aspect of competence. This is considered reasonable because the improvement of the creativity aspect should be done in a practice and the effectiveness aspect is seen when a competence is finished taught and tested.

TABLE 14. Observation Results of Teacher Professionalism Cycle II at SMK Muhammadiyah 1 Bantul

\begin{tabular}{|lllll|}
\hline & Frequency & Percentage & Valid Percentage & Mean \\
Valid Good & 4 & 100.0 & 100.0 & $79.21 \%$ \\
\hline
\end{tabular}

Table 14 indicates the achievement of four professors SMK Muhammadiyah 1 Bantul in cycle II that is equal to $(79.21 \%)$ and is in good category.

TABLE 15. Observation Results of Teacher Professionalism Improvement Cycle II SMK Muhammadiyah 1 Bantul

\begin{tabular}{|ccc|}
\hline $\begin{array}{c}\text { Teacher } \\
\text { Professionalism Cycle } \\
\text { I }\end{array}$ & $\begin{array}{c}\text { Teacher } \\
\text { Professionalism Cycle } \\
\text { II }\end{array}$ & $\begin{array}{c}\text { Teacher } \\
\text { Professionalism } \\
\text { Increase }\end{array}$ \\
\hline $\begin{array}{c}\text { Category } \\
\text { Enough }(53.72 \%)\end{array}$ & $\begin{array}{c}\text { Category } \\
\text { Good }(79.21 \%)\end{array}$ & $25.42 \%$ \\
\hline
\end{tabular}

Table 15 explains that teacher profession in cycle $\mathrm{I}$ is in sufficient category (53.72\%) and increases in cycle II into good category $(79.21 \%)$. The improvement of professionalism teacher in cycle I to cycle II is equal to $(25.42 \%)$. Professional teacher upgrading is indicated by increasing teacher competence, creativity, and teacher effectiveness in teaching. Creativity and innovation can significantly affect the entrepreneurship cultivation process ${ }^{[10]}$. The continuous 
professional development of teachers can be through selfdevelopment investments, scientific publications, and innovative works either independently or in groups

The presentation in the form of histogram used to show the improvement of the professionalism in cycle I and cycle II.

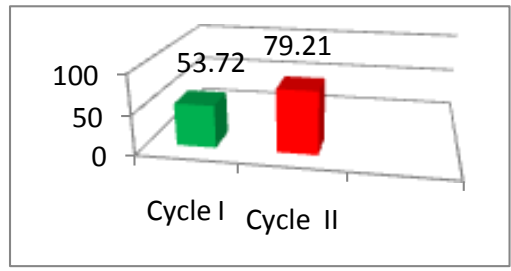

Figure 4. Teacher Professionalism Improvement (Cycle I-Cycle II)

Figure 4 illustrates the increasing trend occurring during cycle I to cycle II, which is $53.72 \%$ to $79.21 \%$.

\section{Results of Teacher Acquisition in Cycle III}

The professionalism of the four teachers of SMK Muhammadiyah 1 Bantul cycle II is (94.78\%). Improvement occurs in all aspects of teacherpreneurship (aspects of competence, creativity, and effectiveness). The most significant improvement occurred in the aspect of creativity. It also supported the results of interviews with teachers that training makes teachers more motivated to be creative in the learning process.

Table 16. Results of Teacher Professionalism Observation Cycle III

\begin{tabular}{|lllll|}
\hline & Frequency & Percentage & Valid Percentage & Mean \\
\hline $\begin{array}{l}\text { Valid Very } \\
\text { Good }\end{array}$ & 4 & 100.0 & 100.0 & $94.78 \%$ \\
\hline
\end{tabular}

Table 16 indicates that the professionalism achievement of four teachers at SMK Muhammadiyah 1 Bantul in cycle III is $(94.78 \%)$ and is in very good category.

Table 17. Observation Results of Teacher Professionalism Improvement Cycle III SMK Negeri 2 Depok

\begin{tabular}{|ccc|}
\hline $\begin{array}{c}\text { Teacher } \\
\text { Professionalism Cycle } \\
\text { II }\end{array}$ & $\begin{array}{c}\text { Teacher } \\
\text { Professionalism Cycle } \\
\text { III }\end{array}$ & $\begin{array}{c}\text { Teacher } \\
\text { Professionalism } \\
\text { Increase }\end{array}$ \\
\hline $\begin{array}{c}\text { Category } \\
\text { Good }(79.21 \%)\end{array}$ & $\begin{array}{c}\text { Category } \\
\text { Very Good }(94.78 \%)\end{array}$ \\
\hline
\end{tabular}

Table 17 explains teacher's professionalism in cycle II is in good category $(79.21 \%)$ then increased in cycle III to very good category (94.78\%). Teacher professionalism improvement in cycle II to cycle III is equal to (13.7\%). Teacher professionalism is indicated by the teacher's creativity while teaching in the classroom ${ }^{[3]}$. The creative thinking ability of teachers need to be developed continuously considering the instructional tools that compiled by the teacher is one of the keys to the successful implementation of learning in the classroom ${ }^{[4]}$.
The presentation in the form of histogram shows the professionalism improvement cycle II and cycle III.

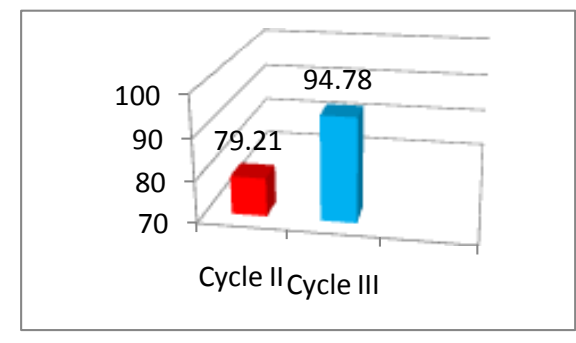

Figure 5. Teacher Professional Improvement (Cycle II-Cycle III)

Figure 5 illustrates the increasing trend that occurs during cycle II to cycle III is $79.21 \%$ to $94.78 \%$.

In general, the improvement of teacherpreneurship implementation to improve teacher professionalism and instill the entrepreneurial spirit in teachers is presented in the following histogram.

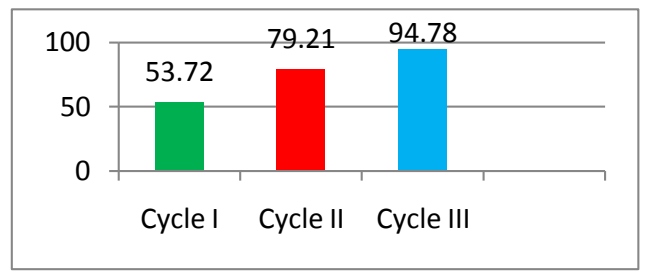

Figure 6. Teacherpreneurship Implementation Improvement of teachers

\section{CONCLUSIONS AND SUGGESTIONS}

Based on the results of the discussion, the following conclusions are obtained: First, the implementation of professionalism of teachers at SMK Negeri 2 Depok and SMK Muhammadiyah 1 Bantul can be seen from three aspects, namely competence, creativity, and effectiveness of teachers when teachers teach. The increase of teacher professionalism at SMK Negeri 2 Depok from cycle I to cycle II is equal to $(23,18 \%)$ and improvement from cycle II to cycle III is equal to $(16,82 \%)$. While the improvement of teacher professionalism at SMK Muhammadiyah 1 Bantul from cycle I to cycle II is equal to $(25,42 \%)$ and improvement from cycle II to cycle III is equal to $(13,07 \%)$.

Second, teacher's opinion on teacherpreneurship implementation is obtained from interviews and notes during observation during field research process. Based on these two things can be concluded that: (1) teachers are very interested about teacherpreneurship because it is considered to be a solution so that learners will not only see the competence of students in terms of competence; (2) teachers feel the development of professionalism in terms of competence, creativity, and effectiveness, and (3) teachers suggest the existence of further research on teacherpreneurship to 
determine the effectiveness of the results of a graduate of SMK in instilling entrepreneurial spirit.

Based on the results of the research in the third cycle of the three aspects of professionalism of teachers (aspects of competence, creativity, and effectiveness) while teaching, the effectiveness of teachers get the lowest score, both are at SMK Negeri 2 Depok with a score $(91.31 \%)$ and at SMK Muhammadiyah 1 Bantul with score $(90.61 \%)$. Therefore, improving the effectiveness of teachers is needed. It can be done through 3 ways: (1) provide training to make models of learning media practices more varied; (2) teaching the training given to students but with different instructional media models; and (3) make car alarms more effective and have sales force.

\section{ACKNOWLEDGMENT}

This research was kindly sponsored by Postgraduate Team of Yogyakarta State University.

\section{REFERENCES}

[1] A. Munandar, Analisis Kesiapan SMK RSBI dalam Peningkatan Daya Saing Lulusan. Jurnal Kependidikan, vol. 43, pp. 78-86, 2013.

[2] Antara, Mengintegrasikan SMK \& Vokasi. Harian Jogja, p. 4, 10 November 2016.
[3] H. Ernani, Kreativitas dan Inovasi Berpengaruh terhadap Kewirausahaan Usaha Kecil. Jurnal Manajemen dan Kewirausahaan, vol. 13, pp. 8-16, 2011.

[4] H. Sapin, Kreativitas Guru Dalam Merancang Lingkungan Sebagai Sumber Belajar Pada Mata Pelajaran Produktif di SMK Gorontalo. Jurnal Penelitian dan Pendidikan, vol. 8, pp. 39-50, 2011.

[5] Marfu'ah, S. et al. Learning goals achievement of a teacher in professional development. Jurnal Pendidikan Teknologi dan Kejuruan vol 23, pp. 295-303, 2017.

[6] Napitupulu, Vokasi Bukan Lagi "Kelas Dua". Kompas, p. 6, 26 Desember 2016

[7] N. Adi, Teacherpreneurship. Yogyakarta: Ar-Ruzzmedia, 2016.

[8] P. Ratna and Alfarisa, Pendidikan Profesi Guru (PPG): Strategi Pengembangan Profesionalitas Guru dan Peningkatan Mutu Pendidikan Indonesia, Yogyakarta: Universitas Negeri Yogyakarta, 2015.

[9] P. W. Rachmat and S. Herminarto, Pengembangan Model Teacherpreneur pada Sekolah Menengah Kejuruan. Jurnal Pendidikan Vokasi, vol. 6, pp. 230-240, 2016.

[10] Sujianto. Pengembangan Profesionalitas Berkelanjutan Guru Bersertifikat /Continuing Professionality Development (CPD) Pendidik di SMK Rumpun Teknologi se-Malang Raya. Jurnal Pendidikan Sains, vol 1, pp 159-170, 2013.

[11] Triyono, M.B. Model Edupreneurship Pelopor SMK Techno, Teacher, and Schoolpreneur. Yogyakarta: Penelitian hibah Pacsarjana tahun pertama UNY. 2015. 